American Journal of Environmental Sciences 4 (2): 164-172, 2008

ISSN 1553-345X

(C) 2008 Science Publications

\title{
Treatment of Stormwater Runoff and Landfill Leachates Using a Surface Flow Constructed Wetland
}

\author{
${ }^{1}$ A. Snow, ${ }^{1}$ A. E. Ghaly and ${ }^{2}$ R. Cote \\ ${ }^{1}$ Department of Process Engineering and Applied Science \\ ${ }^{2}$ School of Resource and Environmental Studies, Dalhousie University, Halifax, Nova Scotia, Canada
}

\begin{abstract}
A surface flow wetland was constructed in the Burnside Industrial Park, Dartmouth, Nova Scotia, to treat stormwater runoff from the surrounding watersheds which are comprised primarily of commercial properties and two former landfills. The aim was to protect a freshwater ecosystem that consists of a $4.6 \mathrm{~km}$ long brook and two lakes. The ability of the constructed wetland to retain iron and manganese from the influent water was investigated and the change in $\mathrm{pH}$ of the water as it flowed through the cells was assessed. In 2004, the total iron removal efficiency of the constructed wetland ranged from a low of $47.13 \%$ to a high of $84.74 \%$ and in 2006 ranged from a low of $35.56 \%$ to a high of $78.49 \%$ depending on rain events. The outlet total iron concentrations in 2006 were not significantly different from those reported for 2004. In 2004, the total manganese removal efficiency of the constructed wetland ranged from a low of $25.75 \%$ to a high of $51.61 \%$ and in 2006 ranged from a low of $0.0 \%$ to a high of $33.33 \%$ depending on rain events. The inlet and the outlet total manganese concentrations in the constructed wetland from August to October 2006 were significantly higher than the inlet and the outlet total manganese concentrations reported for August to October 2004 because water levels in the constructed wetland were very low and the average $\mathrm{pH}$ of the outlet water was lower in 2006. In 2004 and 2006, the $\mathrm{pH}$ of the water in the constructed wetland had average inlet values of 6.70 and 6.26 and average outlet values of 7.28 and 6.70, respectively.
\end{abstract}

Key words: Surface flow wetland, landfill leachates, stormwater, iron, manganese, $\mathrm{pH}$

\section{INTRODUCTION}

Landfills are physical facilities constructed in the surface soils of the earth for the purpose of solid waste disposal. Historically, landfills have been the most economical and environmentally acceptable method for the disposal of solid wastes throughout the world ${ }^{[1]}$. However, landfills generate leachates, which are produced when waters from rain and snow percolate through the waste materials and contaminants are leached into solution. Leachates are one of the main environmental concerns associated with landfills because of their extreme variability in quality and quantity and potential to damage the quality of groundwater, surface water and $\mathrm{soil}^{[2,3]}$. Leachate quality and quantity are affected by a number of factors including the age of the landfill, the waste composition, the landfilling technology and climate conditions ${ }^{[3,4]}$.

Wetlands are ecosystems that are covered by water or have water present near the soil surface for all or part of the year, which results in saturated soils that support aquatic vegetation ${ }^{[5,6]}$. Constructed and natural wetlands have been used to treat many types of wastewaters including landfill leachates ${ }^{[7-9]}$. According to $\mathrm{Ye}$ et $a l .^{[10]}$, constructed wetlands are better able to handle fluctuations in the quality and quantity of wastewater than conventional treatment systems. Wetlands improve water quality through a variety of physical (sedimentation, flocculation, filtration, adsorption), chemical (chelation, precipitation, chemical adsorption) and biological (bacterial mediated reactions, vegetation uptake) mechanisms that operate independently or collectively ${ }^{[11,12]}$.

A surface flow constructed wetland was established in the Burnside Industrial Park, Dartmouth, Nova Scotia, to treat stormwater runoff from the surrounding watersheds (107 ha) which are comprised primarily of commercial and light industrial properties (77 ha) and two former landfills (a 5.34 ha site that operated from 1968 to 1974 and a 5.42 ha site that

Corresponding Author: A. E. Ghaly, Professor, Department of Process Engineering and Applied Science, Dalhousie University, Halifax, Nova Scotia, Canada 
Am. J. Environ. Sci., 4 (2): 164-172, 2008

Table 1: Heavy metal loads entering Wright's Brook

\begin{tabular}{lll}
\hline Element & $\begin{array}{l}\text { Average Concentration } \\
\left(\mathrm{mg} \mathrm{L}^{-1}\right)\end{array}$ & $\begin{array}{l}\text { Guidelines }^{[14]} \\
\left(\mathrm{mg} \mathrm{L}^{-1}\right)\end{array}$ \\
\hline Aluminium & 7.720 & $0.005-0.100$ \\
Arsenic & 0.009 & 0.005 \\
Chromium & 0.013 & $0.001-0.009$ \\
Copper & 0.039 & $0.002-0.004$ \\
Iron & 15.508 & 0.300 \\
Lead & 0.075 & $0.001-0.007$ \\
Manganese & 3.029 & $1.000-1.500^{[15]}$ \\
Zinc & 0.158 & 0.030 \\
\hline
\end{tabular}

operated from 1976 to 1977). The average precipitation for the area from 1971 to 2000 was $116.6 \mathrm{~mm}$ month $^{-1[13]}$. The aim was to protect a freshwater ecosystem that consists of a $4.6 \mathrm{~km}$ long brook (Wright's Brook) and two lakes (Enchanted Lake and Flat Lake). A previously conducted environmental site assessment (Table 1) had determined that the water entering the brook contained average iron and manganese concentrations of $15.508 \mathrm{mg} \mathrm{L}^{-1}$ and 3.029 $\mathrm{mg} \mathrm{\textrm {L } ^ { - 1 }}$, respectively, which exceeds the allowable limits established by the Canadian Water Quality Guidelines for the Protection of Aquatic Life ${ }^{[14,15]}$. The wetland consists of 9 deep open water cells that are separated by shallow internal vegetated berms and surrounded by a system of external berms with a total surface area of $6300 \mathrm{~m}^{2}$ and 2 naturally vegetated islands that are surrounded by a system of external berms with a total surface area of approximately 6100 $\mathrm{m}^{2}$. The wetland berms and cells were planted with a variety of native plant species such as Carex crinita (fringed sedge), Carex lurida (yellow green sedge), Juncus brevicaudatus (tweedy's rush), Juncus effusus (soft rush), Scripus validus (soft stem bulrush), Calamagrostis canadensis (bluejoint grass), Alisma plantagoaquatica (water plantain), Pontederia cordata (pickerelweed), Nymphaea alba (white waterlily) and Potamageton natans (pondweed). The two naturally vegetated islands consist of untamed early successional brush dominated by low shrubs such as Comptonia peregrina (sweet fern), Viburnum cassinoides (witherod) and Spiraea alba (meadowsweet), deciduous and evergreen trees such as Acer rubrum (red maple), Betula papyrifera (white birch) and Picea rubens (red spruce) and emergent macrophytes such as Typha latifolia (cattails).

The objectives of this study were: (a) to evaluate the overall iron and manganese removal efficiencies of the constructed wetland in 2004 and 2006 and (b) to assess the change in water $\mathrm{pH}$ as the water flowed through the wetland cells.

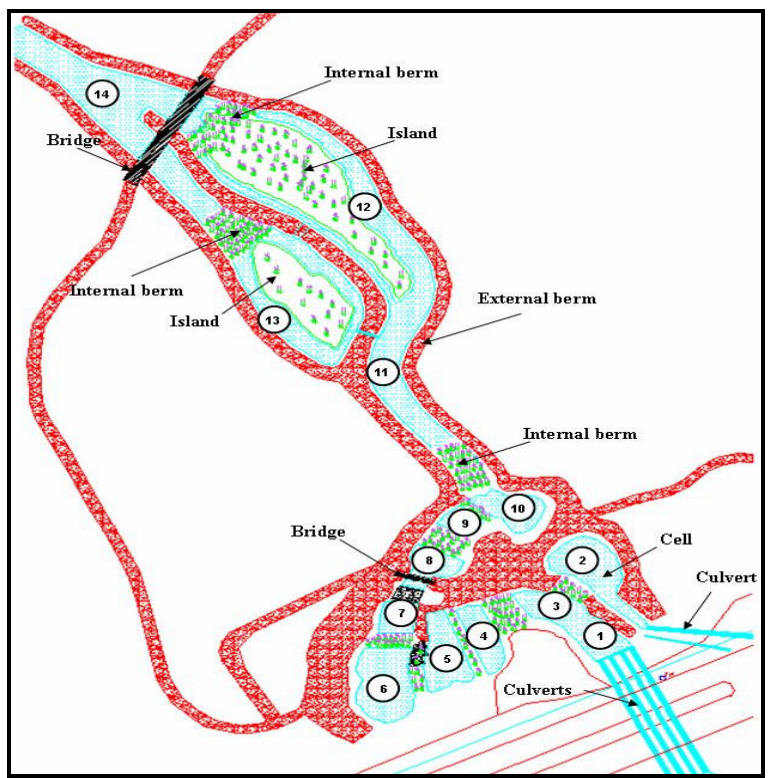

Fig. 1: Location of water samples in the constructed surface flow wetland

\section{MATERIALS AND METHODS}

Biweekly water samples were collected from the constructed wetland during the months of May October. In 2004, water samples were collected from eleven locations in the constructed wetland and in 2006 from fourteen locations (Fig. 1). Grab samples were collected in $500 \mathrm{~mL}$ high density polyethylene (HDPE) bottles using the bottle submersion method ${ }^{[16]}$. The samples were transported to the Environmental Engineering Laboratory at Dalhousie University in Halifax, Nova Scotia and refrigerated at $4{ }^{\circ} \mathrm{C}$ until needed for chemical analyses.

Water samples were analyzed for total iron and total manganese using a spectrophotometer (Model \# DR/2500, Hach Company, Loveland, CO, USA). The FerroVer $^{\circledR}$ Method (Method 8008) was used to measure total iron and the Periodate Oxidation Method (Method 8034) was used to measure total manganese

${ }^{[17]}$. The $\mathrm{pH}$ of the water samples was measured using a $\mathrm{pH}$ meter (Fisher Accumet ${ }^{\circledR} \mathrm{pH}$ meter, Model \# 805MP, Fisher Scientific Co., Ottawa, Ontario, Canada).

The data from 2004 and 2006 were analyzed statistically using a two sample-t-test. The statistical analyses were performed using Minitab (Minitab Release 14.20, Minitab Inc., State College, PA) and differences were considered significant at a p-value $\leq$ 0.05 (95\% confidence interval). 
Am. J. Environ. Sci., 4 (2): 164-172, 2008

\section{RESULTS AND DISCUSSION}

Total iron: Figure 2 displays the total iron concentrations in the inlet and the outlet in 2004 and 2006. The total iron concentration in the constructed wetland fluctuated during the spring - fall period but generally decreased as the water flowed through the cells. The inlet iron concentrations ranged from 6.25 to $7.21 \mathrm{mg} \mathrm{L}^{-1}$ with an average concentration of $6.78 \mathrm{mg}$ $\mathrm{L}^{-1}$ for 2004 and ranged from 2.52 to $17.90 \mathrm{mg} \mathrm{L}^{-1}$ with an average concentration of $8.29 \mathrm{mg} \mathrm{L}^{-1}$ for 2006 . The outlet iron concentration ranged from 0.96 to $3.68 \mathrm{mg}$ $\mathrm{L}^{-1}$ with an average concentration of $2.27 \mathrm{mg} \mathrm{L}^{-1}$ for 2004 and ranged from 1.74 to $3.85 \mathrm{mg} \mathrm{L}^{-1}$ with an average concentration of $2.74 \mathrm{mg} \mathrm{L}^{-1}$ for 2006 .

The iron removal efficiencies for 2004 and 2006 are shown in Table 2. The total iron removal efficiency of the constructed wetland ranged from a low of 47.13 $\%$ to a high of $84.74 \%$ in 2004 and ranged from a low of $35.56 \%$ to a high of $78.49 \%$ in 2006 . The inlet and the outlet total iron concentrations in the constructed wetland in 2006 were compared with those determined in 2004 as shown in Table 3 and 4. The inlet total iron concentrations in September and October of 2006 were significantly higher than the inlet total iron concentrations earlier in the season and in September and October of 2004 (p-value $=0.025$ ). The outlet total iron concentrations in the constructed wetland in 2006 were not significantly different from the outlet total iron concentrations in 2004 (p-value $=0.243$ ). One possible reason for the higher inlet total iron concentrations in September and October 2006 than those observed earlier in the season was that water levels in the constructed wetland in September and October were very low. From August $15^{\text {th }}$ to August $31^{\text {st }}$, 2006, the wetland and surrounding area received a total of 7.6 $\mathrm{mm}$ of rainfall and the total rainfall for the month of September 2006 was only $37 \mathrm{~mm}$. The area also received either small amounts of rainfall or no rainfall in the five days prior to sample collection ${ }^{[18]}$. The lower total iron concentrations in the inlet of the constructed wetland that were observed earlier in the season may have been the result of higher water levels and larger water inflows which diluted the total iron concentrations. Also, the water levels in the constructed wetland in September and October 2006 were lower than in September and October 2004. From August $15^{\text {th }}$ to August $31^{\text {st }}, 2004$, the wetland and surrounding area received a total rainfall of $67 \mathrm{~mm}$ and the total rainfall for the month of September 2004 was $69.2 \mathrm{~mm}^{[18]}$. One would expect an increase in iron removal efficiency overtime. A possible explanation for not observing
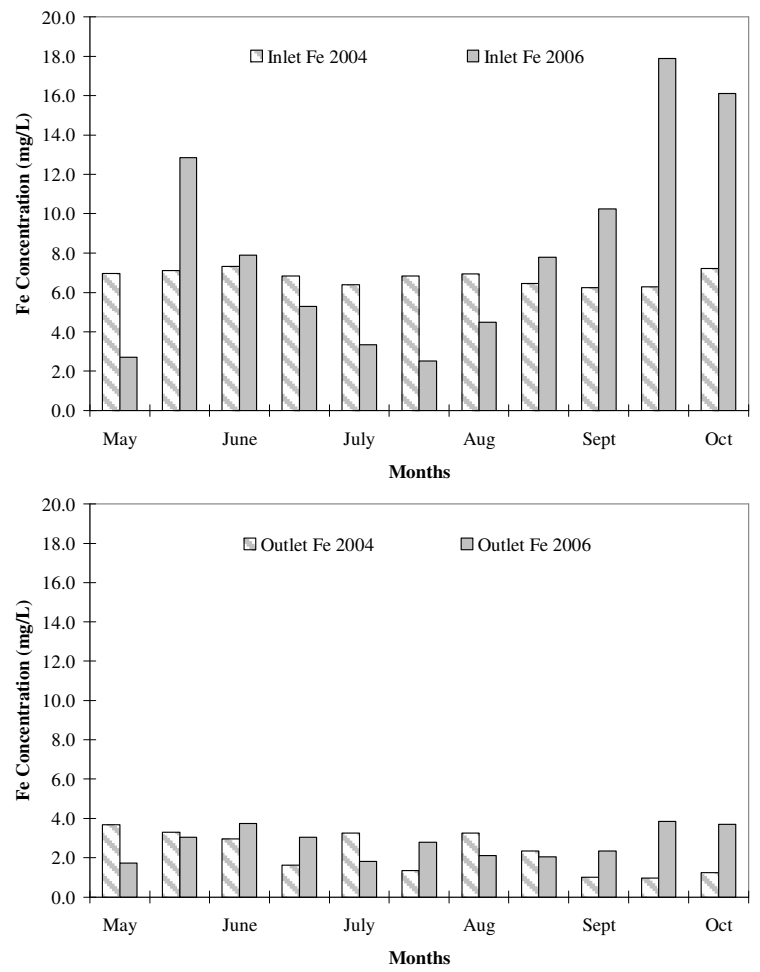

Fig. 2: The inlet and outlet total Fe concentrations in the constructed wetland for the 2004 and 2006 seasons

greater iron removal efficiencies in 2006 was that the inflow of water to the constructed wetland had also increased significantly because of development (servicing and grading) of lots within the industrial park.

Generally, wetlands are capable of removing large quantities of trace elements from wastewaters. However, there is significant variability among trace elements and also between wetlands in the degree to which each element is removed from the wastewater ${ }^{[19]}$. Ye et $a .^{[10]}$ reported that the average removal efficiencies of iron from a surface flow wetland that was constructed to treat coal combustion leachate from an electrical power station in Pennsylvania in the first and second years of the study were 90.8 and $94 \%$, respectively. Eckhardt et al. ${ }^{[20]}$ observed that the average removal efficiency of iron from a surface flow wetland that was constructed to remediate leachate from a landfill in New York was $70.6 \%$. DeBusk ${ }^{[21]}$ reported that the average reduction in iron concentration achieved by a constructed wetland treating landfill leachate in Northwest Florida over a six year period was $98 \%$. 
Am. J. Environ. Sci., 4 (2): 164-172, 2008

Table 2: Fe and Mn removal efficiencies

\begin{tabular}{|c|c|c|c|c|}
\hline \multirow{3}{*}{ Month } & \multicolumn{4}{|c|}{ Removal Efficiency (\%) } \\
\hline & \multicolumn{2}{|c|}{$\mathrm{Fe}$} & \multicolumn{2}{|c|}{$\mathrm{Mn}$} \\
\hline & 2004 & 2006 & 2004 & 2006 \\
\hline \multirow{2}{*}{ May } & 47.13 & 35.56 & 45.50 & 0.00 \\
\hline & 53.79 & 76.26 & 49.75 & 20.00 \\
\hline \multirow{2}{*}{ June } & 59.56 & 52.53 & 33.51 & 28.57 \\
\hline & 76.20 & 42.45 & 25.75 & 20.00 \\
\hline \multirow{2}{*}{ July } & 49.06 & 46.27 & 34.48 & 33.33 \\
\hline & 80.29 & -10.32 & 33.33 & 9.09 \\
\hline \multirow{2}{*}{ August } & 53.24 & 53.13 & 34.43 & -33.33 \\
\hline & 63.57 & 73.72 & 28.26 & -50.00 \\
\hline \multirow{2}{*}{ September } & 83.68 & 77.07 & 45.79 & -25.00 \\
\hline & 84.74 & 78.49 & 50.77 & -12.50 \\
\hline October & 82.94 & 77.02 & 51.61 & -28.57 \\
\hline Average & 66.75 & 54.74 & 39.38 & -3.49 \\
\hline
\end{tabular}

Table 3: Two-sample t-test for the inlet total Fe concentrations in the constructed wetland from September to October 2004 and 2006

\begin{tabular}{llllllll}
\hline Source & $\mathrm{n}$ & $\mathrm{DF}$ & $\mathrm{M}$ & $\sigma$ & SE & T-value & P-value \\
\hline Inlet Fe 2004 & 3 & 4 & 6.583 & 0.543 & 0.31 & -3.50 & 0.025 \\
Inlet Fe 2006 & 3 & 4 & 14.75 & 4.00 & 2.30 & & \\
\hline
\end{tabular}

Differences are considered significant at a p-value $\leq 0.05$ (95\% confidence interval)

Table 4: Two-sample t-test for the outlet total Fe concentrations in the constructed wetland from May to October 2004 and 2006

\begin{tabular}{llllllll}
\hline Source & $\mathrm{n}$ & $\mathrm{DF}$ & $\mathrm{M}$ & $\sigma$ & $\mathrm{SE}$ & T-value & P-value \\
\hline Outlet Fe 2004 & 11 & 20 & 2.27 & 1.05 & 0.32 & -1.20 & 0.243 \\
Outlet Fe 2006 & 11 & 20 & 2.747 & 0.793 & 0.24 & & \\
\hline Differences are considered significant at a p-value $\leq 0.05$ & $(95 \%$ confidence interval)
\end{tabular}

Differences are considered significant at a p-value $\leq 0.05$ (95\% confidence interval)

According to Hall et al. ${ }^{[22]}$, one of the fundamental processes responsible for successful iron removal in surface flow (aerobic) wetlands is the oxidation of ferrous iron $\left(\mathrm{Fe}^{2+}\right)$ to ferric iron $\left(\mathrm{Fe}^{3+}\right)$ and the hydrolysis of $\mathrm{Fe}^{3+}$ to ferric iron hydroxide $\mathrm{Fe}(\mathrm{OH})_{3}$ as shown in the following equations. Precipitates such as $\mathrm{Fe}(\mathrm{OH})_{3}$, cause an orange staining and sludge build up on substrate surfaces ${ }^{[23]}$.

$\mathrm{Fe}^{2+}+1 / 4 \mathrm{O}_{2}+\mathrm{H}^{+} \rightarrow \mathrm{Fe}^{3+}+1 / 2 \mathrm{H}_{2} \mathrm{O}$

$\mathrm{Fe}^{3+}+3 \mathrm{H}_{2} \mathrm{O} \rightarrow \mathrm{Fe}(\mathrm{OH})_{3}+3 \mathrm{H}^{+}$

Hedin and Nairn ${ }^{[24]}$ state that the removal of iron from aerobic waters with a $\mathrm{pH}>4$ is limited by the oxidation process (Equation 1). At a $\mathrm{pH}>6$, abiotic oxidation processes dominate over bacterial oxidation processes. In natural systems with circumneutral $\mathrm{pH}$ values, the kinetics of abiotic oxidation processes are typically 5 - 10 times faster than biological mechanisms of oxidation at lower $\mathrm{pH}$ values. Ferric iron hydrolysis occurs quickly at a $\mathrm{pH} \geq 3.5^{[23]}$.

A second mechanism for iron removal from wastewater in constructed wetlands is the formation of insoluble metal sulphides by sulphate reducing bacteria in anoxic zones. Sulphate reducing bacteria are obligate anaerobes that require a $\mathrm{pH}$ in the range of $5-8$ in order to survive. Sulphate reducing bacteria oxidize simple organic compounds $\left(\mathrm{CH}_{2} \mathrm{O}\right)$ and use sulphate $\left(\mathrm{SO}_{4}{ }^{2-}\right)$ as the terminal electron acceptor. The result is the production of hydrogen sulphide $\left(\mathrm{H}_{2} \mathrm{~S}\right)$ which reacts with iron and forms insoluble iron sulphide $(\mathrm{FeS})$ as shown in the following equations ${ }^{[25]}$.

$2 \mathrm{CH}_{2} \mathrm{O}+\mathrm{SO}_{4}{ }^{2-} \rightarrow \mathrm{H}_{2} \mathrm{~S}+2 \mathrm{HCO}_{3}^{-}$

$\mathrm{Fe}^{2+}+\mathrm{H}_{2} \mathrm{~S} \rightarrow \mathrm{FeS}+2 \mathrm{H}^{+}$

The iron precipitates formed in the above two mechanisms are subject to adsorption by wetland substrates and filtration and sedimentation in wetland cells. Vegetation is also of primary importance for iron retention in wetlands. Plants play a critical role in iron removal via filtration of water and adsorption of iron and iron particulates on submerged stems and leaves. Plants can excrete oxygen via their root mass into the surrounding sediment which makes their rhizosphere more aerobic and more favourable for $\mathrm{Fe}^{3+}$ precipitation. Plants provide habitat and energy sources to maintain and stimulate a diverse microbial population in the wetland. Plants also participate in iron retention in wetlands via phytoremediation ${ }^{[6,10,25]}$.

In the present study, the primary sink for metal retention in the constructed wetland is the bottom sediments because the $\mathrm{pH}$ of the water is greater than 6 and substantial orange staining and sludge have been observed in the wetland cells. A second important mechanism is adsorption of iron precipitates on the submerged stems of Potamageton natans (pondweed). According to Ye et al $^{[26]}$, approximately 40 to $70 \%$ of the total iron retained by wetlands was found as ferric hydroxides. Plant uptake and retention of metals was 
generally small compared to sediment accumulation and typically accounted for $<5 \%$ of the metals retained in a wetland ${ }^{[12,19]}$.

Total manganese: Figure 3 displays the total manganese concentrations in the inlet and the outlet in 2004 and 2006. In 2004, the manganese concentration generally decreased as the water flowed through the cells, but did not appear to significantly increase or decrease as the water flowed through the cells in 2006. The inlet manganese concentration ranged from 1.67 to $2.32 \mathrm{mg} \mathrm{L}^{-1}$ with an average concentration of $1.91 \mathrm{mg}$ $\mathrm{L}^{-1}$ for 2004 and ranged from 4.0 to $0.1 \mathrm{mg} \mathrm{L}^{-1}$ with an average concentration of $1.7 \mathrm{mg} \mathrm{L}^{-1}$ for 2006. For 2004, the maximum manganese concentration in the outlet was $1.52 \mathrm{mg} \mathrm{L}^{-1}$ while the minimum manganese concentration was $0.9 \mathrm{mg} \mathrm{L}^{-1}$ with an average of 1.16 $\mathrm{mg} \mathrm{\textrm {L } ^ { - 1 }}$ while for 2006, the highest manganese concentration observed in the effluent was $5.0 \mathrm{mg} \mathrm{L}^{-1}$ and the lowest concentration was $0.1 \mathrm{mg} \mathrm{L}^{-1}$ with an average concentration of $1.9 \mathrm{mg} \mathrm{L}^{-1}$.

The manganese removal efficiencies of the constructed wetland for 2004 and 2006 are shown in Table 2. In 2004, the total manganese removal efficiency of the constructed wetland ranged from a low of $25.75 \%$ to a high of $51.61 \%$ with an average removal efficiency of $39.38 \%$. In 2006, the total manganese removal efficiency of the constructed wetland ranged from a low of $0.0 \%$ to a high of 33.33 $\%$. However, there were higher manganese concentrations in the outlet than in the inlet in the months of August - October of 2006.

The inlet and the outlet total manganese concentrations in the constructed wetland in 2006 were compared to the inlet and the outlet total manganese in 2004 as shown in Table 5 and 6 . The inlet and the outlet total manganese concentrations in the constructed wetland from August to October 2006 were significantly higher than the inlet and the outlet total manganese concentrations earlier in the season and from August to October 2004 ( $\mathrm{p}$-value $=0.051$ and 0.019). A possible reason for the higher total manganese concentrations in the inlet and the outlet of the constructed wetland from August to October 2006 than those observed earlier in the season and from August to October 2004 was that water levels in the constructed wetland from the middle of August to October were very low. The lower total manganese concentrations in the inlet and the outlet earlier in the season may have been the result of higher water levels and larger water inflows which diluted the total manganese concentrations. Also, the average $\mathrm{pH}$ of the
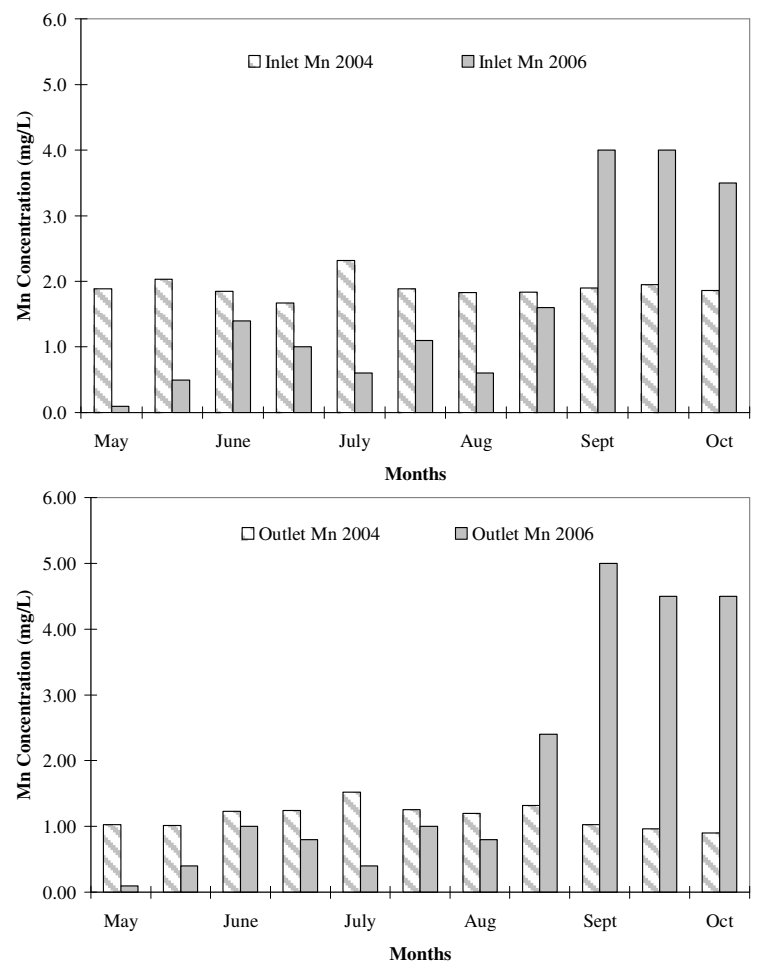

Fig. 3: The inlet and outlet total Mn concentrations in the constructed wetland for the 2004 and 2006 seasons

outlet water was 6.70 in 2006 and 7.27 in 2004. A higher $\mathrm{pH}$ is more favourable for manganese oxidation.

According to Komnitsas et al. ${ }^{[27]}$ and Gazea et $a l .{ }^{[23]}$, manganese is very difficult to remove from solution because it is an extremely mobile ion. Elevated levels of manganese may be caused by re-dissolution of unstable precipitates or desorption of manganese from surfaces. Gazea et $a l .{ }^{[23]}$ state that when both iron and manganese are present in solution, manganese removal will be less efficient than iron removal because iron and manganese precipitation occur sequentially. Ferrous iron also has the ability to reduce insoluble forms of manganese to $\mathrm{Mn}^{2+}$ as shown in the following equations ${ }^{[19,23]}$.

$\mathrm{MnO}_{2(\mathrm{~S})}+2 \mathrm{Fe}^{2+}+2 \mathrm{H}_{2} \mathrm{O} \rightarrow 2 \mathrm{FeOOH}_{(\mathrm{S})}+\mathrm{Mn}^{2+}+2 \mathrm{H}^{+}$

$\mathrm{MnOOH}_{(\mathrm{S})}+\mathrm{Fe}^{2+} \rightarrow \mathrm{FeOOH}_{(\mathrm{S})}+\mathrm{Mn}^{2+}$

Hallberg and Johnson $^{[28]}$ note that biological oxidation of manganese does not proceed rapidly in the presence of iron and thus it is not removed significantly in aerobic wetlands where the concentration of ferrous iron exceeds $1 \mathrm{mg} \mathrm{L}^{-1}$. According to Sobolewski ${ }^{[19]}$, Gazea et al. ${ }^{[23]}$ and Hallberg and Johnson ${ }^{[28]}$ a second reason manganese removal may not be as successful as 
iron removal is that abiotic $\mathrm{Mn}^{2+}$ oxidation occurs slowly at $\mathrm{pH}$ values $<8$. The average $\mathrm{pH}$ of the outlet water in the constructed wetland in 2006 was 6.70 .

Ye et al. ${ }^{[10]}$ reported that the average manganese removal efficiencies of a surface flow wetland that was constructed to remediate coal combustion leachate were 91 and $98 \%$ in the first and second years of the study, respectively. The authors contributed the significant manganese retention in the constructed wetland to the high $\mathrm{pH}$ of the water $(\mathrm{pH}>7.2)$. Ye et al. ${ }^{[26]}$ conducted a study to determine the ability of a 10 year old surface flow constructed wetland to treat coal ash leachate from an electrical utility in Alabama. The study focused on metal removal from the first two vegetated wetland cells. The degree to which the concentration of manganese was reduced in the outlet water from cell 2 varied considerably between sampling times and ranged from a low of $-7 \%$ in May 1996 to a high of $26 \%$ in August 1996. During this time, the average $\mathrm{pH}$ of the water within the wetland was 3.9. In order to increase the manganese removal efficiency of the wetland, the authors added sodium hydroxide to cell 1. As a result, the $\mathrm{pH}$ in the outlet water from cell 2 rose to greater than 6 and the manganese removal efficiency reached $58 \%$. DeBusk ${ }^{[21]}$ reported that the average manganese removal efficiency achieved by a surface flow wetland treating municipal landfill leachate was $95 \%$ over a six year period.

One possible mechanism for manganese removal in aerobic wetlands involves the oxidation of dissolved $\mathrm{Mn}^{2+}$ to the tetravalent form $\mathrm{Mn}^{4+}$, which is similar to ferrous iron oxidation. Then, the hydrolysis of $\mathrm{Mn}^{4+}$ produces $\mathrm{MnO}_{2}$ as shown in the following equations ${ }^{[24]}$.

$\mathrm{Mn}^{2+}+1 / 2 \mathrm{O}_{2}+2 \mathrm{H}^{+} \rightarrow \mathrm{Mn}^{4+}+\mathrm{H}_{2} \mathrm{O}$

$\mathrm{Mn}^{4+}+2 \mathrm{H}_{2} \mathrm{O} \rightarrow \mathrm{MnO}_{2}+4 \mathrm{H}^{+}$

$\mathrm{Mn}^{2+}$ can also precipitate in the form of carbonate in alkaline environments, which in the presence of oxygen may further oxidize to $\mathrm{MnO}_{2}$ as shown in the following equations ${ }^{[23]}$.

$\mathrm{Mn}^{2+}+\mathrm{HCO}_{3} \rightarrow \mathrm{MnCO}_{3(\mathrm{~s})}+\mathrm{H}^{+}$

$\mathrm{MnCO}_{3}+\mathrm{O}_{2} \rightarrow \mathrm{MnO}_{2}+\mathrm{CO}_{2}$

pH: Figure 4 displays the $\mathrm{pH}$ in the inlet and the outlet in 2004 and 2006. In 2004, the pH of the water in the constructed wetland fluctuated as the water flowed through the cells whereas in 2006, the $\mathrm{pH}$ of the water increased as the water flowed through the cells. The inlet $\mathrm{pH}$ values ranged from 6.70 to 7.60 with an average value of 6.70 for 2004 and ranged from 6.13 to 6.55 with an average value of 6.26 for 2006 . The maximum $\mathrm{pH}$ in the outlet was 7.60 while the minimum $\mathrm{pH}$ was 6.70 with an average of 7.28 for 2004 and ranged from 6.55 to 6.91 with an average value of 6.70
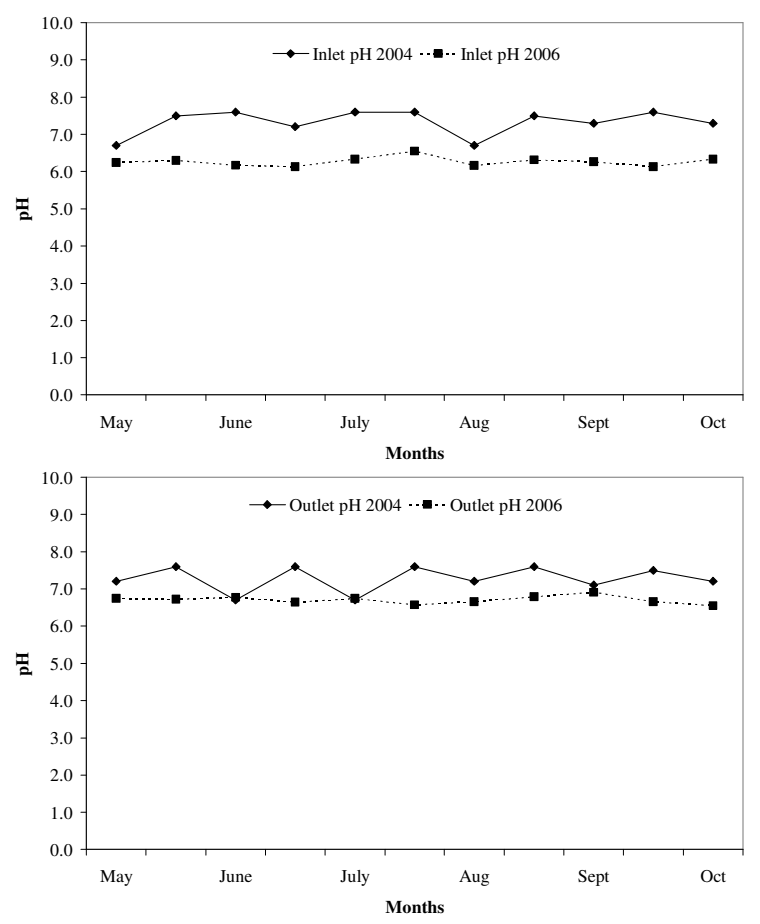

Fig. 4: The inlet and outlet $\mathrm{pH}$ values in the constructed wetland for the 2004 and 2006 seasons

for 2006. The inlet and the outlet water $\mathrm{pH}$ in the constructed wetland in 2006 were compared to the inlet and the outlet water $\mathrm{pH}$ in the constructed wetland in 2004 as shown in Table 7 and 8. The inlet and the outlet water $\mathrm{pH}$ values in the constructed wetland in 2006 were significantly lower than the inlet and the outlet water $\mathrm{pH}$ values in the constructed wetland in 2004 (pvalue $=0.000)$.

One possible explanation for the increase in $\mathrm{pH}$ in 2006 was the presence of rapidly growing algae and submerged aquatic vegetation in the constructed wetland which remove carbon dioxide $\left(\mathrm{CO}_{2}\right)$ from the water during photosynthesis as shown in Equation 11. A decrease in the dissolved $\mathrm{CO}_{2}$ concentration in the water results in a lower concentration of carbonic acid $\left(\mathrm{H}_{2} \mathrm{CO}_{3}\right)$ as shown in Equation 12. As the $\mathrm{H}_{2} \mathrm{CO}_{3}$ concentration in the water decreases, the concentration of $\mathrm{H}^{+}$decreases as shown in Equation 13. As a result, the $\mathrm{pH}$ of the water within the wetland increases ${ }^{[29]}$.

$6 \mathrm{H}_{2} \mathrm{O}+6 \mathrm{CO}_{2}+$ light energy $\rightarrow \mathrm{C}_{6} \mathrm{H}_{12} \mathrm{O}_{6}+6 \mathrm{O}_{2}$

$\mathrm{CO}_{2}+\mathrm{H}_{2} \mathrm{O} \leftrightarrow \mathrm{H}_{2} \mathrm{CO}_{3}$

$\mathrm{H}_{2} \mathrm{CO}_{3} \leftrightarrow \mathrm{H}^{+}+\mathrm{HCO}_{3}^{-}$

The increase in $\mathrm{pH}$ could also be due to bacterial sulphate reduction in anaerobic zones within the wetland. Bacterial sulphate reduction (Equation 3) within the anaerobic zones of wetlands produces bicarbonate ions $\left(\mathrm{HCO}_{3}\right)$, which results in a decrease in 
Am. J. Environ. Sci., 4 (2): 164-172, 2008

Table 5: Two-sample t-test for the inlet total Mn concentrations in the constructed wetland from August to October 2004 and 2006

\begin{tabular}{llllllll}
\hline Source & $\mathrm{n}$ & $\mathrm{DF}$ & $\mu$ & $\sigma$ & $\mathrm{SE}$ & $\mathrm{T}$-value & P-value \\
\hline Inlet Mn 2004 & 4 & 6 & 1.8875 & 0.0486 & 0.024 & -2.43 & 0.051 \\
Inlet Mn 2006 & 4 & 6 & 3.28 & 1.14 & 0.57 & & \\
\hline
\end{tabular}

Differences are considered significant at a p-value $\leq 0.05$ (95\% confidence interval)

Table 6: Two-sample t-test for the outlet total Mn concentrations in the constructed wetland from August to October 2004 and 2006

\begin{tabular}{llllllll}
\hline Source & $\mathrm{n}$ & $\mathrm{DF}$ & $\mu$ & $\Sigma$ & SE & T-value & P-value \\
\hline Outlet Mn 2004 & 5 & 8 & 1.082 & 0.174 & 0.078 & -2.94 & 0.019 \\
Outlet Mn 2006 & 5 & 8 & 3.49 & 1.78 & 0.80 & & \\
\hline
\end{tabular}

Differences are considered significant at a p-value $\leq 0.05$ (95\% confidence interval)

Table 7: Two-sample t-test for the inlet water $\mathrm{pH}$ in the constructed wetland in 2004 and 2006

\begin{tabular}{llllllll}
\hline Source & $\mathrm{n}$ & $\mathrm{DF}$ & $\mu$ & $\sigma$ & $\mathrm{SE}$ & T-value & P-value \\
\hline Inlet $\mathrm{pH} 2004$ & 11 & 20 & 7.327 & 0.341 & 0.10 & 9.73 & 0.000 \\
Inlet pH 2006 & 11 & 20 & 6.265 & 0.123 & 0.037 & & \\
\hline
\end{tabular}

Differences are considered significant at a p-value $\leq 0.05$ (95\% confidence interval)

Table 8: Two-sample t-test for the outlet water $\mathrm{pH}$ in the constructed wetland in 2004 and 2006

\begin{tabular}{lllllll}
\hline Source & $\mathrm{n}$ & $\mathrm{DF}$ & $\mu$ & $\sigma$ & SE & T-value \\
\hline Outlet pH 2004 & 11 & 11 & 7.273 & 0.344 & 0.10 & 5.25 \\
Outlet pH 2006 & 11 & 11 & 6.705 & 0.103 & 0.031 & 0.000 \\
\hline
\end{tabular}

Differences are considered significant at a p-value $\leq 0.05$ (95\% confidence interval)

$\mathrm{H}^{+}$concentration and an increase in $\mathrm{pH}$ as shown in Equation $13^{[25]}$.

A possible explanation for the lower $\mathrm{pH}$ of the water in the constructed wetland in 2006 compared to 2004 was the build up of organic matter within the wetland cells during the period of 2004 - 2006. The decomposition of organic substances is a natural source of acidity in a wetland ${ }^{[30]}$. In shallow wetlands, aerobic decomposition occurs in the entire water body including the upper sediment layers. During the process of aerobic decomposition, microorganisms use dissolved oxygen to oxidise organic compounds into $\mathrm{CO}_{2}, \mathrm{H}_{2} \mathrm{O}$, inorganic compounds $\left(\mathrm{NH}_{4}{ }^{+}, \mathrm{SO}_{4}{ }^{-2}\right.$ and $\left.\mathrm{PO}_{4}{ }^{-3}\right)$ and energy. Anaerobic decomposition occurs in anoxic zones and anaerobic sediments in wetlands. In order for anaerobic decomposition to occur, nitrate, nitrite or sulphate must be available. Organic carbon can be completely mineralized to $\mathrm{CO}_{2}$ or $\mathrm{CO}_{2}$ and methane $\left(\mathrm{CH}_{4}\right)$. In most freshwater wetland sediments, methanogenesis is the common pathway for organic matter decomposition and the most frequent mechanism of $\mathrm{CH}_{4}$ formation in freshwater environments involves the substrate acetate $\left(\mathrm{CH}_{3} \mathrm{COOH}\right)$ as shown in Equation $14^{[31,32]}$.

$$
\mathrm{CH}_{3} \mathrm{COOH} \rightarrow \mathrm{CO}_{2}+\mathrm{CH}_{4}
$$

An increase in the dissolved $\mathrm{CO}_{2}$ concentration in the water results in a higher concentration of carbonic acid $\left(\mathrm{H}_{2} \mathrm{CO}_{3}\right)$ as shown in Equation 12. As the $\mathrm{H}_{2} \mathrm{CO}_{3}$ concentration in the water increases so does the concentration of $\mathrm{H}^{+}$as shown in Equation 13 and as a result, the $\mathrm{pH}$ of the water within the wetland decreases.
A second possible explanation for the lower $\mathrm{pH}$ of the water in the constructed wetland in 2006 compared to 2004 was the build up of iron and manganese precipitates in the wetland as the wetland gets older. The hydrolysis and precipitation of dissolved iron (Equation 1) and manganese (Equation 6) and the formation of insoluble metal sulphides (Equation 4) increases the $\mathrm{H}^{+}$concentration in the water and decreases the $\mathrm{pH}$.

Eckhardt et al.$^{[20]}$ reported that the $\mathrm{pH}$ of the water in a surface flow wetland that was constructed to remediate leachate from a landfill in New York increased from 6.9 in the inlet to 7.4 in the outlet. Sartaj ${ }^{[8]}$ recorded that the $\mathrm{pH}$ of the water in a surface flow wetland that was constructed to treat leachate from a landfill in Ontario increased from values of $6.5-7.6$ in the inlet water to values as high as 9 in the outlet water. Johnson et al. ${ }^{[3]}$ reported that the $\mathrm{pH}$ of the water in a surface flow wetland constructed to treat groundwater contaminated with leachate from a landfill in Alabama ranged from 5.33 to 7.05 in the inlet water and 6.06 to 7.95 in the outlet water.

\section{CONCLUSION}

In 2004, the total iron removal efficiency of the constructed wetland ranged from a low of $47.13 \%$ to a high of $84.74 \%$ and in 2006 ranged from a low of $35.56 \%$ to a high of $78.49 \%$ depending on rain events. The outlet total iron concentrations in 2006 were not significantly different from those reported for 2004. 
In 2004, the total manganese removal efficiency of the constructed wetland ranged from a low of $25.75 \%$ to a high of $51.61 \%$ and in 2006 ranged from a low of 0.0 $\%$ to a high of $33.33 \%$ depending on rain events. There were higher manganese concentrations in the outlet than in the inlet in the months of August - October 2006 because water levels in the constructed wetland from the middle of August to October were very low. The inlet and the outlet total manganese concentrations from August to October 2006 were significantly higher than the inlet and the outlet total manganese concentrations reported for August to October 2004 because water levels in the constructed wetland were very low and the average $\mathrm{pH}$ of the outlet water was lower in 2006. In 2004 and 2006, the $\mathrm{pH}$ of the water in the constructed wetland had average inlet values of 6.70 and 6.26 and average outlet values of 7.28 and 6.70, respectively. The inlet and the outlet water $\mathrm{pH}$ in 2006 were significantly lower than those reported for 2004.

\section{ACKNOWLEDGEMENTS}

This research was funded by the ELJB Foundation of Montreal and Environment Canada.

\section{REFERENCES}

1. Tchobanoglous, G., H. Theisen and S. Vigil, 1993. Integrated Solid Waste Management: Engineering Principles and Management Issues. McGraw-Hill, Boston, Massachusetts, pp: 361-538.

2. Aziz, H.A., M.S. Yusoff, M.N. Adlan, N.H. Adnam and S. Alias, 2004. Physico chemical removal of iron from semi-aerobic landfill leachate by limestone filter. Waste Manage., 24: 353-358.

3. Johnson, K.D., C.D. Martin, G.A. Moshiri and W.C. McCrory, 1999. Performance of a constructed wetland leachate treatment system at the Chunchula Landfill, Mobile County, Alabama. In: Mulamoottil, G., E.A. McBean and F. Rovers (Eds.). Constructed Wetlands for the Treatment of Landfill Leachates. Lewis Publishers, Boca Raton, Florida, pp: 57-70.

4. Christensen, T.H., P. Kjeldsen, P.L. Bjerg, D.L. Jensen, J.B. Christensen, A. Baun, H.J. Albrechtsen and G. Heron, 2001. Biogeochemistry of landfill leachate plumes. Appl. Geochem., 16: 659-718.

5. Mitsch, W.J. and J.G. Gosselink, 2000. Wetlands. John Wiley \& Sons, Inc., New York.

6. Noller, B.N., P.H. Woods and B.J. Ross, 1994. Case studies of wetland filtration of mine waste water in constructed and naturally occurring systems in Northern Australia. Water, Sci. Technol., 29: 257-265.
7. Schwartz, L.N., L.P. Wiseman and E.L. Melear, 1999. Leachate wetland treatment system in Orange County, Florida. In: Mulamoottil, G., E. A. McBean and F. Rovers (Eds.). Constructed Wetlands for the Treatment of Landfill Leachates. Lewis Publishers, Boca Raton, Florida, pp: 99-140.

8. Sartaj, M., L. Fernandes and N. Castonguay, 1999. Treatment of leachate from a landfill receiving industrial, commercial, institutional and construction/demolition wastes in an engineered wetland. In: Mulamoottil, G., E. A. McBean and F. Rovers (Eds.). Constructed Wetlands for the Treatment of Landfill Leachates. Lewis Publishers, Boca Raton, Florida, pp: 165-174.

9. La Forge, F., L. Fernandes and M.A. Warith, 1999. Attenuation of landfill leachate by a natural marsh system. In: Mulamoottil, G., E. A. McBean and F. Rovers (Eds.). Constructed Wetlands for the Treatment of Landfill Leachates. Lewis Publishers, Boca Raton, Florida, pp: 141-150.

10. Ye, Z.H., S.N. Whiting, Z.-Q. Lin, C.M. Lytle, J.H. Qian and N. Terry, 2001. Removal and distribution of iron, manganese, cobalt and nickel within a Pennsylvania constructed wetland treating coal combustion by-product leachate. J. Environ. Qual., 30: 1464-1473.

11. Mitchell, G.F., C.L. Hunt and Y. Su, 2002. Mitigating highway runoff constituents via a wetland. Transport. Res. Rec., 1808: 127-133.

12. Dunbabin, J.S. and K.H. Bowmer, 1992. Potential use of constructed wetlands for treatment of industrial wastewaters containing metals. Sci. of the Total Environ., 111: 151-168.

13. Environment Canada, 2004. Canadian Climate Normals 1971-2000. Shearwater A, Nova Scotia. Retrieved on August 3, 2007, from http://www.climate.weatheroffice.ec.gc.ca

14. CCME, 2005. Canadian Environmental Quality Guidelines. Retrieved on August 20, 2006, from http://www.ccme.ca

15. BCMELP, 2001. Ambient Water Quality Guidelines for Manganese. Retrieved September 14, 2002, from http://wlapwww.gov.bc.ca/wat/wq/BCguidelines/m anganese.html

16. Byrnes, M.E., 1994. Field Sampling Methods for Remedial Investigations. Lewis Publishers, Boca Raton, Florida.

17. Hach Company, 2002. Water Analysis Handbook. $4^{\text {th }}$ edition. Hach Company, Loveland, Colorado.

18. Environment Canada, 2007. National climate data and information archive. Retrieved on February 15, 2007, from http://www.weatheroffice.ec.gc.ca 
19. Sobolewski, A., 1999. A review of processes responsible for metal removal in wetlands treating contaminated mine drainage. Intl. J. Phytoremediation, 1: 19-51.

20. Eckhardt, D.A.V., J.M. Surface and J.H. Peverly, 1999. A constructed wetland system for treatment of landfill leachate, Monroe County, New York. In: Mulamoottil, G., E. A. McBean and F. Rovers (Eds.). Constructed Wetlands for the Treatment of Landfill Leachates. Lewis Publishers, Boca Raton, Florida, pp: 205-222.

21. DeBusk, W.F., 1999. Evaluation of a constructed wetland for treatment of leachate at a municipal landfill in Northwest Florida. In: Mulamoottil, G., E. A. McBean and F. Rovers (Eds.). Constructed Wetlands for the Treatment of Landfill Leachates. Lewis Publishers, Boca Raton, Florida, pp: 175186.

22. Hall, G., P. Swash and S. Kotilainen, 2005. The importance of biological oxidation of iron in the aerobic cells of the Wheal Jane pilot passive treatment system. Sci. of the Total Environ., 338: 67-72.

23. Gazea, B., K. Adam and A. Kontopoulos, 1996. A review of passive systems for the treatment of acid mine drainage. Minerals Engg., 9: 23-42.

24. Hedin, R.S. and B. Nairn, 1993. Contaminant removal capabilities of wetlands constructed to treat coal mine drainage. In: Moshiri, G.A. (Edr). Constructed Wetlands for Water Quality Improvement. Lewis Publishers, Boca Raton, Florida, pp: 187-195.
25. Cohen, R.R.H., 2006. Use of microbes for cost reduction of metal removal from metals and mining industry waste streams. J. Cleaner Production, 14: 1146-1157.

26. Ye, Z.H., S.N. Whiting, J.H. Qian, C.M. Lytle, Z.Q. Lin and N. Terry, 2001. Trace element removal from coal ash leachate by a 10-year-old constructed wetland. J. Environ. Qual., 30: 1710-1719.

27. Komnitsas, K., G. Bartzas and I. Paspaliaris, 2004. Efficiency of limestone and red mud barriers: Laboratory column studies. Minerals Engg., 17: 183-194.

28. Hallberg, K.B. and B.D. Johnson, 2005. Biological manganese removal from acid mine drainage in constructed wetlands and prototype bioreactors. Sci. of the Total Environ., 338: 115-124.

29. Tchobanoglous, G. and E.D. Schroeder, 1985. Water Quality. Addison-Wesley, Menlo Park, California.

30. Kadlec, R.H. and R.L. Knight, 1996. Treatment Wetlands. Lewis Publishers, New York.

31. Christensen, T.R., A. Ekberg, L. Strom, M. Mastepanov, N. Panikov, M. Oquist, B.H. Svensson, H. Nykanen, P.J. Martikainen and H. Oskarsson, 2003. Factors controlling large scale variations in methane emissions from wetlands. Geophys. Res. Lett., 30: 1-4.

32. Tanner, C.C., D.D. Adams and M.T. Downes, 1997. Methane emissions from constructed wetlands treating agricultural wastewaters. J. Environ. Qual., 26: 1056-1062. 